TREATMENT OF HYPOPYON ULCERS WITH Albucid and Proflavine

\title{
TREATMENT OF HYPOPYON ULCERS WITH ALBUCID AND PROFLAVINE*
}

BY

Capt. P. D. Trevor-Roper, N.Z.M.C.

Although the number of cases that I have treated has been lamentably small, I feel justified in mentioning them partly because circumstances are now so rare which allow an assessment of novel treatments on any quantity of in-patients-and so far as I know this has not yet been performed for albucid-and partly also in the desire to bring to notice the use of proflavine as an antiseptic for the conjunctival sac.

Albucid has been shown to be an effective bactericide when introduced into the conjunctival sac, and one which penetrates the corneal tissues well; and although there is little recorded clinical evidence of its value, it has already become widely. adopted as a routine treatment of corneal and conjunctival infections. Eighteen months ago I published a series of out-patient cases (conjunctivitis and corneal ulcers), treated with albucid drops, and in these no advantage over previous methods was apparent; but as the patients could not be persuaded to instill the drops more than thrice daily this does not criticise its use in the more serious cases where hospitalisation is necessary.

Recently I have treated a similar series of in-patient cases of hypopyon ulcer with albucid, instilling 30 per cent. drops hourly by day and 10 per cent. ointment 4-hourly by night for 4 days, then 10 per cent. ointment thrice daily; in four cases I used the glass shell container as advocated by Brigadier Scott so as to keep the albucid solution in contact with the eye for a longer time (10 minutes in practice) but this so irritated the inflamed eye that none could well tolerate it. As the results were not encouraging, in the next dozen cases I used proflavine for a course of three days with an irrigation of 0.1 per cent. solution of proflavine in saline 2 -hourly by day and 4-hourly by night, and material improvement ensued.

Proflavine is a recently introduced flavine derivative of great bactericidal power, inhibiting in vitro staph. aureus in $1 / 10,000$ concentration or $1 / 80.000$ in the absence of serum, and pneumococcus in $1 / 100,000$ in the presence or absence of serum; the toxicity to tissues is considerably less than that of the other flavine antiseptics, indeed so non toxic as to justify its wide use as a powder in general surgery, very little microscopical tissue damage has been shown by Professor McIntosh to be thus produced, and $\mathrm{Mr}$. Mottram has shown that no ill-effects follow injection of $\frac{1}{2}$ c.c.

*Read at the meeting of the Section of Ophthalmology, Royal Society of Medicine November 12, 1943. 
$1 / 1,000$ proflavine in saline into the tail vein of the mouse. Finally no signs of irritation have been observed after its introduction into the conjunctival sac of patients.

\section{Cases Treated With albucid}

\begin{tabular}{|c|c|c|c|c|c|}
\hline Name & Age & Culture & Previous history & $\begin{array}{l}\text { Size of } \\
\text { Hy popyon }\end{array}$ & Result \\
\hline J. H. & 53 & Pneumococcus & Painful 4 days & $1 \frac{1}{2} \mathrm{mms}$ & Hypopyon cleared in \\
\hline B. J. & 66 & - & - & $1 \frac{1}{2} \mathrm{mms}$ & $\begin{array}{l}\text { Hypopyon cleared in } \\
9 \text { days }\end{array}$ \\
\hline J. B. & 58 & - & Painful 1 month & $2 \mathrm{mms}$. & $\begin{array}{l}\text { Hypopyon cleared in } \\
5 \text { days }\end{array}$ \\
\hline N. C. & 42 & - & Painful 6 weeks & $1 \mathrm{~mm}$ & $\begin{array}{l}\text { Hypopyon cleared in } \\
4 \text { days }\end{array}$ \\
\hline H. G. & 66 & - & Painful 4 days & $1 \frac{1}{2} \mathrm{mms}$ & $\begin{array}{l}\text { Hypopyon cleared in } \\
4 \text { days }\end{array}$ \\
\hline A. M. & 59 & - & Painful 3 days & $1 \mathrm{~mm}$. & $\begin{array}{l}\text { Hypopyon cleared in } \\
5 \text { days }\end{array}$ \\
\hline L. P. & 44 & - & - & $1 \mathrm{~mm}$ & $\begin{array}{l}\text { Transferred I.S. Q. in } \\
3 \text { days }\end{array}$ \\
\hline J. H. & 36 & $\begin{array}{l}\text { Pneumobacillus } \\
\text { and s. aureus }\end{array}$ & & $2 \mathrm{mms}$ & $\begin{array}{l}\text { Transferred I. S. Q. in } \\
21 \text { days }\end{array}$ \\
\hline F. D. & 48 & - & Painful 2 days & $2 \mathrm{mms}$ & $\begin{array}{l}\text { Transferred I. S. Q. in } \\
42 \text { days, finally healed } \\
\text { after T.A.B. injection }\end{array}$ \\
\hline F.J. & 19 & - & Painful 10 days & $2 \mathrm{mms}$ & $\begin{array}{l}\text { Saemisch section } 11 \\
\text { days }\end{array}$ \\
\hline T. G. & 80 & 一 & Painful 2 days & $2 \mathrm{mms}$. & $\begin{array}{l}\text { Saemisch section in } \\
10 \text { days followed by } \\
\text { evisceration }\end{array}$ \\
\hline F. W. & 82 & - & Painful 2 days & $3 \mathrm{mms}$. & $\begin{array}{l}\text { Saemisch section in } \\
10 \text { days followed by } \\
\text { evisceration }\end{array}$ \\
\hline
\end{tabular}

Treated With Oral Sulphapyidine

\begin{tabular}{|c|c|c|c|c|c|}
\hline Name & Age & Culture & Previous history & $\begin{array}{l}\text { Size of } \\
\text { Hy popyon }\end{array}$ & Result \\
\hline J. C. & 8 & - & Painful 2 days & 2 mms. & Evisceration in 16 days \\
\hline
\end{tabular}

Cases Treated With Proflavine

Hypopyon Ulcers

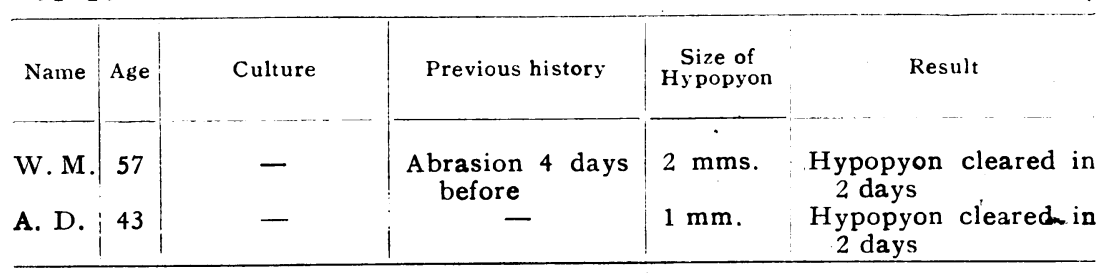


TREATMENT OF HYPOPYON ULCERS WITH Albucid and Proflavine

Cases Treated With Proflavine-continued.

Hypopyon Ulcers

\begin{tabular}{|c|c|c|c|c|c|}
\hline Name & Age & Culture & Previous history & $\begin{array}{l}\text { Size of } \\
\text { Hypopyon }\end{array}$ & Result \\
\hline F. S. & 40 & Pneumobacillus & Abrasion 2 days & $1 \mathrm{~mm}$. & Hypopyon cleared in \\
\hline F. P. & 46 & - & F.B. 2 days before & 3 mms. & $\begin{array}{l}\text { Hypopyon cleared in } \\
5 \text { days }\end{array}$ \\
\hline J. F. & 17 & Pneumococcus & F.B. 1 day before & $2 \mathrm{mms}$. & $\begin{array}{l}\text { Hypopyon cleared in } \\
2 \text { days }\end{array}$ \\
\hline J. B. & 8 & - & 一 & $1 \mathrm{~mm}$ & $\begin{array}{l}\text { Hypopyon cleared in } \\
1 \text { day }\end{array}$ \\
\hline E. $\mathbf{M}$. & 58 & - & Sore 7 days & $2 \mathrm{mms}$. & $\begin{array}{l}\text { Hypopyon cleared in } \\
3 \text { days }\end{array}$ \\
\hline H. B. & 47 & - & F.B. 4 days & $1 \frac{1}{2} \mathrm{mms}$. & $\begin{array}{l}\text { Hypopyon cleared in } \\
\text { J day }\end{array}$ \\
\hline W. C. & 46 & 一 & $\begin{array}{l}\text { Ulcer treated for } \\
1 / 12 \text { following } \\
\text { F.B. }\end{array}$ & $1 \frac{1}{2} \mathrm{mms}$. & $\begin{array}{l}\text { Hypopyon cleared in } \\
1 \text { day, recurred from } \\
\text { 3rd to } 5 \text { th day after } \\
\text { discontinuance of } \\
\text { proflavine }\end{array}$ \\
\hline E. W. & 66 & $一$ & Sore 4 days before & 2 mms. & $\begin{array}{l}\text { Saemisch section } 5 \\
\text { days }\end{array}$ \\
\hline J. R. & 71 & 一 & - & 2 mms. & $\begin{array}{l}\text { Saemisch section } 7 \\
\text { days }\end{array}$ \\
\hline C. $\mathrm{K}$. & 62 & - & $\begin{array}{c}\text { Abrasion } 4 \text { days } \\
\text { before }\end{array}$ & $3 \mathrm{mms}$. & $\begin{array}{c}\text { Saemisch section } 2 \\
\text { days }\end{array}$ \\
\hline Hypo & pyo & n Iritis & & & \\
\hline D. C. & 47 & - & $\begin{array}{c}\text { Relapse } \\
\text { before }\end{array}$ & $1 \mathrm{~mm}$ & $\begin{array}{l}\text { Hypopyon cleared in } \\
2 \text { days }\end{array}$ \\
\hline R. H. & 44 & - & Painful 30 days & $1 \mathrm{~mm}$ & $\begin{array}{l}\text { Hypopyon cleared in } \\
1 \text { day }\end{array}$ \\
\hline J. $\mathrm{H}$. & 47 & - & $\begin{array}{c}\text { Relapse } \\
\text { before }\end{array}$ & $2 \mathrm{mms}$. & $\begin{array}{l}\text { Hypopyon cleared in } \\
1 \text { day, recurrence in } \\
3 \text { days and then } \\
\text { cleared in further } \\
5 \text { days }\end{array}$ \\
\hline
\end{tabular}

In all cases atropine, heat, diathermy, covering and rest were given in addition to the specific drug mentioned.

It will be seen that 12 cases of hypopyon ulcers have been treated with albucid, 12 with proflavine, and 1 with oral sulphapyridine (as the latter had an untoward end this was not tried again); three cases also of hypopyon iritis received the regime of proflavine irrigations and all rapidly responded:

In all but four cases no pathogenic bacteria were found on culture from the conjunctival sac; and in these four, further culture after use of the bactericide was sterile.

In three of each series of 12 , usually in the very old cases, Saemisch section was required, those in the proflavine series being all over 60 , and the two octogenarians of the albucid series both lost the eye. In the remaining 18 cases, all had a history of only, a few days of pain; in all those treated with proflavine the hypopyon cleared rapidly in an average of two days; but among those treated 
with albucid, in 6 the hypopyon cleared in an average of 5.3 days, and in the remaining 3 it was still present on their transference to a base hospital in 3,21 and 42 days respectively.

Although as a criterion of efficacy the clearance of the hypopyon is not without criticism, it was the only one practicable since it was sometimes necessary to discharge the patient before the final healing of the ulcer itself owing to shortage of beds.

It is of interest that one persistent hypopyon cleared only after a course of T.A.B. injections, and in several cases the ulcer itself healed only, but then invariably, after recourse to the latter.

This assay is far from comprehensive, but there seems little doubt that proflavine will be of value in superficial eye infections, especially when the optimum vehicle and concentrations have been détermined.

I should like to thank Mr. Mottram and Professor McIntosh for their help and the use of their unpublished findings.

\title{
A CASE OF EXŨDATIVE AND HAEMORRHAGIC RETINITIS, WITH INCREASED INTRA-OCULAR TENSION, TREATED BY PILOCARPINE AND THYROID*
}

\author{
BY \\ A. LANDAU \\ CONSULTING PHYSICIAN AT PADEREWSKI \\ HOSPITAL, EDINBURGH \\ and \\ J. RUSZKOWSKI \\ LECTURER IN OPHTHALMOLOGY, IN POLISH. \\ MEDICAL SCHOOL, EDINBURGH
}

Patient P., female, age 40 years, married, nulliparous, reported to us in December, 1941. She complained of a troublesome pain in her right eye-ball, and right-sided headaches, and stated that her right eye had been blind for two years.

In 19.37 she was involved in a motor accident receiving a severe blow above her right eye. A week later she noticed a dark spot in front of her eye. An ophthalmologist found a patchy retinal haemorrhage. Since the accident her sight has become steadily worse and, being haunted by the fear of blindness, the patient commenced a "pilgrimage" all over Europe from one eye specialist to another.

Two months after the accident, one of the specialists found increased intra-ocular tension and performed an anti-glaucomatous 